\title{
Determinants of Adoption and Extent of Agricultural Intensification in the Central Mid-hills of Nepal
}

\author{
Nani Raut (Corresponding author) \\ Department of International Environment and Development Studies (Noragric) \\ Agricultural University of Norway, P.O. Box 5001, N-1432 Ås, Norway \\ Tel: 47-64-965-340Ｅ-mail: nani.raut@umb.no \\ Bishal K. Sitaula \\ Department of International Environment and Development Studies (Noragric) \\ Agricultural University of Norway, P.O. Box 5001, N-1432 Ås, Norway \\ Arild Vatn \\ Department of International Environment and Development Studies (Noragric) \\ Agricultural University of Norway, P.O. Box 5001, N-1432 Ås, Norway \\ Giridhari S. Paudel \\ Family Planning Association of Nepal, P.O. Box 486, Kathmandu, Nepal
}

Received: May 11, 2011

Accepted: June 29, 2011

doi:10.5539/jsd.v4n4p47

\begin{abstract}
The problems encountered by Nepalese farmers in the adoption of agricultural intensification (AI), and the constraints and complexities of sustainable AI are not thoroughly understood. This study analyzed factors influencing the adoption and extent of AI at household level in the Ansikhola watershed in the central mid-hills of Nepal. Data were collected from a survey of 310 households, four key informant interviews, and two focus group discussions. The results reveal that $63 \%$ of the sampled households practice AI, with differences in the area under cropping intensification. The binary logistic regression model results show that irrigation facility, higher crop yield, landholding size, access to credit, and distance to chemical fertilizer store have significant influences on adoption. Likewise, the linear regression model results show that total amount of fertilizer application, net income from cereals and vegetables, and distance to the chemical fertilizer store have significant influences on the extent of AI. The results of this study could contribute to formulating policies based on farmers' need, interest, and capacity in promoting sustainable agricultural intensification.
\end{abstract}

Keywords: Agricultural intensification, Adoption, Logistic regression, Linear regression

\section{Introduction}

Agriculture plays a vital role in the economy of developing countries, providing employment for more than $60 \%$ of populations and generating $27 \%$ of the gross national product in South Asia (DFID, 2002). In particular, agricultural development is significant in countries like Nepal, where about $80 \%$ of the Nepalese population are dependent on it. The average landholding size in Nepal decreased by 0.17 ha, from 0.96 ha in 1991/1992 to 0.79 ha in 2001/2002 (CBS, 2002). Such a trend has seriously threatened the livelihood and food security of those who depend on agriculture (Thapa \& Niroula 2008). The problem is more severe for mid-hill farmers where the availability of productive arable land is limited. The middle mountain region of Nepal covers $42 \%$ of the country's total land area and supports about $44 \%$ of the population (CBS, 2003). A gradually decreasing farmland per capita and lack of off-farm employment opportunities affect socio-economic condition of mid-hill farmers (Tiwari et al., 2008a). As a result, a high rate of seasonal migration to urban areas has occurred (Sharma, 2008). With the aim of promoting the growth and extension of agricultural activities, the Agricultural Perspective Plan (APP) of 1995 emphasized yield-increasing technology, intensive land use, and high-value crops, with four priority areas for development: irrigation, fertilizer, technology and infrastructure. The APP also prioritized hill areas with the package centered on high-value commodities such as vegetables, livestock production (specifically milk), apiculture and sericulture. Thus, there is trend towards commercial farming and intensified agricultural in the areas close to city (Dahal et al., 2009; Chapagain, 2006; Brown \& Shrestha, 2000).

The drivers of agricultural intensification (AI) have been viewed from different schools of thought. Boserup (1965) emphasizes that population growth induces AI, which is still considered to be a simple and widely established concept for measuring agricultural change. Pingali et al. (1987) hypothesize that AI can occur in 
response to accessibility to markets and good prices for agricultural products, even though the population density may be low. The decision to adopt agricultural innovations can be understood from the perspective of diffusion of innovation. According to Rogers (1995), an individual's innovation-decision process undergoes five steps: knowledge, persuasion, decision, implementation and confirmation. The adoption of an innovation is influenced by information about the receivers' socio-economic characteristics, social systems, and the characteristics of the innovation. Moreover, the innovation-decision process can lead to either adoption (a decision to make full use of an innovation), or rejection (a decision to maintain the original). This theory has been corroborated and expanded from different dimensions - in particular, the question as to what drives AI has been a matter of concern for researchers and policymakers for some time. There are various factors at macro and micro levels which are expected to influence farmers' decision about the adoption of AI (Nepal \& Thapa, 2009; Knowler \& Bradshaw, 2007; Paudel \& Thapa, 2004; Fafchamps \& Shilpi, 2003; Lele \& Stone, 1989; Weitz et al., 1976; Christaller, 1933). Socio-economic characteristics such as gender, ethnicity and education are considered as precursor factors and have significant effects on the decision-making process (Nepal \& Thapa, 2009; Knowler \& Bradshaw, 2007; Paudel \& Thapa, 2004). It has been found that relatively well-educated people tend to adopt innovations more readily than less educated ones (Lapar \& Ehui, 2004). Sometimes the decision on adoption is influenced by farmers' knowledge and perceptions about how to use scientific knowledge (Schultz, 1964).

Hierarchically organized urban centers are considered to be prime drivers of development, including agricultural commercialization. Urban centers consist of large non-agricultural populations that exert a substantial demand for agricultural products (Christaller, 1933). The distance to urban centers and the biophysical condition of rural areas also encourage agricultural land uses in areas surrounding urban centers (Fafchamps \& Shilpi, 2003). These researchers found that products with a high market value, such as vegetables and milk, were common in the immediate vicinity of a city, while the outer vicinity was found to produce items with a lower market demand, such as cereals. Indeed, small and medium size urban centers make significant contributions to agricultural diversification, while big cities often encumber the development of their rural surrounding areas. Therefore, there is a need for strengthening rural-urban linkages in the interests of unbiased regional development (Douglass, 1998; Johnson, 1970).

Agricultural policy adopted by a particular country in order to promote agricultural development plays a central role in agricultural change through extension services, development of technologies, subsidies, credit, and access to market (Lele \& Stone, 1989). Institutional involvement equally plays an influential role in facilitating particular paths of agricultural intensification (Carswell, 2000). Extension services may be provided through formal and informal institutions, and are a key factor in making farmers aware of and enabling them to promote new agricultural technologies (Thapa \& Rattanasuteerakul, 2010; Paudel \& Thapa, 2004). Key factors that facilitate agricultural diversity and commercialization are the rapid development of technologies; changes in agricultural production practices, such as improved seeds, chemical fertilizer use, technologies to control weeds and harvesting; improved rural infrastructure; and diversification in food demand patterns (Pingali \& Rosegrant, 1995). Access to credit may enable farmers to adopt more capital intensive methods of production (Hazarika \& Alwang, 2003). The development of agriculture may be increased if appropriate institutional systems for marketing farm products, agricultural inputs, credit systems and professional advice are provided (Weitz et al., 1976).

Although Nepal's policies, for example the APP, have promoted AI, the problems encountered by farmers in the adoption of AI, and the constraints and complexities of sustainable AI, are not thoroughly understood (Carswell, 2000). For example, AI near urban centers (Dahal et al., 2009; Brown \& Shrestha, 2000) has increased the use of chemical fertilizer for high value crops (Brown \& Shrestha, 2000). This may have led to soil acidification in the hill areas of Nepal (Bajracharya \& Sherchan, 2009). The misconception still exists among farmers that high doses of chemical fertilizer and pesticides increase productivity. Understanding sustainable AI requires an understanding of farmers' interests, and evaluation of intensification processes. Although numerous studies have examined agricultural commercialization and soil management in Nepal (Thapa \& Rattanasuteerakul, 2010; Tiwari et al., 2008a; Paudel \& Thapa, 2004), few have examined the determinants of AI. This paper firstly examines factors that affect the adoption of AI, focusing on socio-economic, bio-physical and institutional factors. Secondly, since there are differences in the coverage of AI in the Ansikhola watershed in particular, this paper explains the varied extent of AI, thus establishing a new foundation for developing agricultural policies in Nepal.

\section{Research methods}

\subsection{Study area}

The study area comprises the Ansikhola sub watershed located in the Kavre district of central Nepal (Fig. 1). It extends over an area of 13 square $\mathrm{km}$ in the mid-hills region of the country. The elevation of the watershed ranges from $800 \mathrm{~m}$ to $2000 \mathrm{~m}$. The mean annual rainfall amounts to $1389 \mathrm{~mm}$, while the mean annual maximum and minimum air temperatures in the area are $25^{\circ} \mathrm{C}$ and $17^{\circ} \mathrm{C}$ respectively, with annual relative humidity recorded at 74\% (Dahal et al., 2007). The agricultural land is predominantly moderately deep, loamy soil. 
The cultivated land areas are of two main types: 1) Bari - the rainfed upland leveled or sloping terraces, and 2) Khet - the leveled terraces, generally located near streams. The Bari lands are grouped into two types, namely Gharbari (close vicinity to the homestead areas), and Pakhobari (less productive, separate plots, usually away from the homestead). Khet lands are also grouped into two types, namely Galkhet (terraces with irrigation facilities) and Tarkhet (terraces that are not irrigated and depend on monsoon rain). The cropping pattern in all land types is highly diverse (Table 1). Although three crops per year have been adopted in Gharbari, Galkhet and Tarkhet, it has increased significantly in Galkhet from 1987 to 2009, compared to other land types. Since Galkhet has irrigation facilities, there is the possibility to increase the area under three crops. Thus Galkhet was chosen for this study which investigates factors explaining the adoption or non-adoption of AI at farmers' household level.

\subsection{Collection of data}

The Ansikhola sub watershed comprises a total of 12 wards from four VDCs (Village Development Committees), namely: Devitar (1 ward), Anaikot (3 wards), Nayagaon (6 wards) and Mahadevsthan (2 wards), and a total of 1038 households. The primary data were collected by means of a household survey, group discussions, and key informant interviews. A random sampling procedure was undertaken for the household survey. A sample of 315 households was chosen from the total of 1038 households in the watershed. A structured questionnaire, comprising both closed and open-ended questions, was prepared and pre-tested with respondents from the Cha watershed (a watershed with the similar biophysical and socio-economic conditions as Ansikhola) to ensure validity. The survey was conducted between April and July 2009 by two trained enumerators who interviewed heads of the sample households using the questionnaire. Detailed information was collected about their socio-economic conditions, institutional support, landholdings, distance of their land from the motor road, livestock holdings, cropping patterns, labor use, type and amount of fertilizer use, irrigation facilities, labor investment priority, and status of extension services. The data from five of the respondents were discarded since they did not hold any land under intensified agriculture with increased number of crops and use of chemical fertilizer. Hence out of 315 respondents, 310 were included in the analysis, accounting for about $30 \%$ of the total farmers in the watershed.

Further discussions and interviews were held with groups of farmers and key informants. Qualitative information was collected through two group discussions that were conducted separately with men and women, to elicit open responses. The purpose of gathering the data was explained briefly at the beginning of each group discussion. Key informant interviews were undertaken with four elderly farmers (aged at least 60 years): two each from lowland and upland areas of the watershed. Direct field observations were also made to cross check the data obtained from interviews. The additional information was used in the analysis to complement the information gathered from the questionnaire.

\subsection{Determination of dependent variables}

AI in the mid-hills is characterized by triple annual crop rotations that incorporate shorter growing season varieties and no fallow period (Dahal et al., 2007; Westarp et al., 2004). The national average number of crops per annum has increased from 1.6 in 1987 to 2.7 in 1990s for irrigated agriculture (Schreier et al., 1994; Panth \& Gautam 1987). Farmers in the study area are growing different types of crops such as rice, potato, maize, vegetables, wheat and millet (Table 1). The most significant change in cropping patterns in Galkhet is the introduction of potato as a winter crop and spring paddy. The degree of adoption and diversity of crops, however, vary from one household to another and from one land type to another. This represents a typical feature of smallholder agriculture in developing countries where farmers are confronted with numerous production risks (Ellis, 1989; Thapa \& Niroula, 2008). Despite owning small landholdings, most farmers in the study area are strongly oriented towards market focused production.

$\mathrm{AI}$ in the mid-hills is reflected by the fact that the typical two crops per year has been changing to three crops per year. Therefore, the number of crops adopted by farmers was considered to be an indicator of intensification and chosen as the dependent variable for adoption of AI model. The dependent variable for the adoption model indicates whether or not a farmer has adopted AI. In this study, a farmer who has adopted at least three crops per year was defined as an adopter. A value of 1 was assigned to respondents who adopted AI (the "adopters") and 0 to respondents practicing traditional agricultural system i.e. two crops per year (the "non-adopters"). Whether or not to adopt $\mathrm{AI}$ is influenced by different explanatory variables in this study (see Table 2 and section 2.4).

Factors influencing the extent of AI by individual farm respondents were analyzed by using a stepwise linear regression model for which it was also necessary to determine a dependent variable. The "area used for cultivation of at least three crops per annum" was chosen as the dependent variable, which varied from one farm household to another. Those respondents who were cultivating a maximum of two crops per year were not included in the analysis.

\subsection{Selection of explanatory variables}

Initially, fifteen independent variables were considered for inclusion in the logistic regression model. A multivariate-correlation analysis was done to determine the co-linearity effect of the independent variables 
(Tiwari et al., 2008a; Paudel \& Thapa, 2004). Any independent variables with a high degree of correlation $(\mathrm{r}>$ 0.5 ) with each other and a low degree of correlation with the dependent variable were excluded from the model. This applied to the total amount of fertilizer used. Therefore, a total of fourteen independent variables were included in the logistic regression model (see Table 2 for further details). For the linear regression model, fourteen independent variables with no co-linearity were included since of the fifteen variables, landholding size (area used for cultivation of three crops) had been chosen as the dependent variable.

'Caste' is a dummy variable created using the scoring method and specifying the caste of the respondent. In the Nepalese context, the society is divided into three broad castes based on the profession of the people (Tiwari et al., 2008a; Paudel \& Thapa, 2004). A score of three was allocated to the upper castes (Brahmin/Chhetri), two to the middle castes (Newar \& Janajati), and one to the lower castes (Damai, Kami etc.). Historically the upper castes tend to be more engaged in agriculture compared to middle and lower caste people. However, the scenario has been changing recently as middle and lower caste people are beginning to adopt vegetable farming due to the direct benefits it offers (Tiwari et al., 2008b). 'Gender' is a dummy variable (female $=1 ; 0$ otherwise) that is used to separate the sex of the respondents. Households headed by a male are expected to have greater chances of adoption than those headed by a female (Tiwari et al., 2008a). 'Education' is a variable measuring the level of education of the respondent. It is hypothesized that education of the respondent is positively related to adoption of AI - educated farmers are more likely to be early adopters (Nkamleu \& Adesina, 2000). 'Occupation' is a dummy variable (only agriculture $=1 ; 0$ otherwise). The major occupations of the respondents are agriculture; agriculture and business; agriculture and service holders; and teacher. It is hypothesized that farmers whose main occupation is agriculture are adopters of AI.

'Distance', a continuous variable, is the distance to farm plots from the farm house, measured in $\mathrm{km}$. The closer the plot is to the dwelling, the greater are the possibilities of supervision by the farmer's family (Xuefeng et al., 2008). It is hypothesized that the higher the 'crop yield' from maize and rice, the greater is the possibility of their adoption, with increased cropping frequency. Thus farmers are expected to adopt AI when the farm plot is closer and the yield is higher. 'Agricultural labor input' refers to the total number of laborers involved in the farming activities. Sufficient labor availability often enhances the intensification process. 'CF distance' measures the distance from the homestead to chemical fertilizer stores. A distant market may hinder timely access to the supply of agro-inputs (Adesina, 1996). Thus it is hypothesized that the adoption of AI and use of chemical fertilizers is negatively related to greater CF distance. Farmers owning larger landholdings may be able to invest in new technologies and thus achieve better returns. Thus it is expected that 'landholding size' is positively related to the adoption of AI. 'Income' measures the net income accrued from selling vegetables and cereals. It is hypothesized that higher income implies the ability to invest in crop intensification and to bear the associated risks, thus positively influencing adoption. It is also expected that larger 'cattle herd size' increases the amount of manure produced and thus positively influences the intensification process.

The variables 'access to credit' and 'help from extension workers' are dummy variables (yes $=1 ; 0$ otherwise) that specify if the farmer has received credit for agricultural activities, or assistance from extension workers respectively. Both variables are hypothesized to positively influence the adoption of AI (Table 2).

\subsection{Model specification}

\section{Binary logistic regression model: Adoption of AI}

The objective of the research was to understand the degree and the trend of the relationship between dependent and independent variables in terms of AI. Since the adoption of AI is a dichotomous or binary dependent variable, with the option of either adoption or non-adoption, the binary logistic regression model was applied as the most appropriate tool to investigate how each independent variable affects the probability of the occurrence of events (Long \& Freese, 2006). The logistic regression model explores the socio-economic, institutional and spatial factors influencing the adoption of AI. Thus it helps to explore the degree and direction of relationship between dependent and independent variables in the adoption of AI at the household level. Accordingly, AI in the study area is influenced by a set of independent variables and is specified as follows:

$\operatorname{Ln}\left[P_{i} /\left(1-P_{i}\right)\right]=\beta_{0}+\beta_{1} \mathrm{X}_{1 i}+\beta_{2} \mathrm{X}_{2 i}+\ldots \ldots \ldots+\beta_{\mathrm{k}} \mathrm{X}_{\mathrm{k} i}$

where the subscript $\mathrm{i}$ means the ith observation in the sample. $\mathrm{P}$ is the probability that a farmer adopts the intensification and (1-P) is the probability that a farmer does not adopt AI. $\beta_{0}$ is the intercept term and $\beta_{1}$, $\beta_{2}, \ldots \ldots \ldots, \beta_{k}$ are the coefficients of the independent variables $X_{1}, X_{2}, \ldots \ldots \ldots, X_{k}$.

Linear regression model: Extent of AI

Since the dependent variable "area used for cultivation of at least three crops per annum" is a quantitative variable, the stepwise linear regression model was considered to be an appropriate analytical tool for this analysis. This model has a high ability to incorporate the effects of each independent variable on the dependent variable. The extent of AI measured as the area under the three cropping system by individual farmers, is influenced by a set of independent variables specified in the following model:

$\mathrm{Y}=\mathrm{b}_{0}+\mathrm{b}_{1} \mathrm{X}_{1}+\mathrm{b}_{2} \mathrm{X}_{2}+\ldots \ldots \ldots+\mathrm{b}_{\mathrm{n}} \mathrm{X}_{\mathrm{n}}$ 
where $\mathrm{Y}$, the dependent variable, is the area under the three cropping system, $\mathrm{b}_{0}$ is the intercept, and $\mathrm{b}_{1}$, $b_{2}, \ldots \ldots \ldots, b_{n}$ are the coefficients of the independent variables $X_{1}-X_{n}$.

\section{Results and discussion}

\subsection{Characteristics of adopters and non-adopters}

Of the 310 respondents analyzed in this study, $63 \%$ of them were identified as adopters of AI. There was no significant difference in socio-economic condition (caste, gender, education, occupation and income) between adopters and non-adopters of AI. The continuous variables such as crop yield (composite yield of maize and rice), labor input, irrigation and landholding size, were significantly higher among adopters. The chi-square tests show that access to credit is significantly higher among adopter farmers (Table 2).

\subsection{Factors motivating farmers to adopt intensification}

Farmers reported eight major factors which motivated them to adopt three crops, including availability of high yielding varieties, a food deficit situation, market value of the crops, access to chemical fertilizers, access to pesticides, access to labor, irrigation facilities and access to the motor road (Fig 2). Of these eight factors, farmers were asked to rank their top three factors as first, second and third based on their own priorities. The first, second and third priorities were then coded respectively with values of three, two and one, and the total priority was calculated by adding these values. Results show that forty-four percent of the respondents mentioned that a food deficit situation for more than three months motivated them, and thus their wish to maximize food for own consumption was the main reason for adopting three crops. Twenty nine percent of the respondents mentioned that the establishment of irrigation canal in the watershed was the onset point for the introduction of cereals, and therefore they were influenced to adopt this innovation. Thus irrigation facility was the second highest factor that motivated farmers to adopt three crops a year. Fifteen percent of the respondents indicated that the higher market value of production was the third major reason motivating them to grow three crops.

\subsection{Analysis of determinants of the adoption of AI}

Table 3 shows the indicators, magnitude and statistical significance of the estimated parameter for adoption using the logistic regression model. The log likelihood is 222 and overall, the model correctly predicted $86 \%$ of the variation in the adoption behavior of the farmers.

The model output reveals that eight variables positively influenced, and six variables negatively influenced the adoption of AI. However, statistically, five out of the total fourteen variables significantly influenced the adoption of AI. Four of the five significant variables had a positive influence on the adoption of AI, namely: irrigation, crop yield, landholding size, and access to credit (Table 3). This shows that farmers with a larger landholding size who were satisfied with the yield of crops have an inclination to shift from traditional to intensified agricultural systems. Likewise, irrigation facilities and credit access motivated farmers to adopt AI. In contrast, the distance to the chemical fertilizer store had a significant negative influence on the behavior of farmers towards the adoption of AI. The magnitude of the regression coefficient indicates that positively influencing factors have more influencing power on the adoption of AI than does the negatively influencing factor.

The adoption of any agricultural innovation is influenced by factors such as characteristics of the farmers, characteristics of the innovations, and social circumstances (Rogers, 1995). Results of this study show that irrigation facilities is the most significant factor influencing adoption, in this case, a tendency towards increased adoption of a three cropping system. Discussions with the separate male and female groups revealed that AI in the study area started with the introduction of irrigation canals in 1954. Although sugar cane had already been used by some farmers before the irrigation canals were constructed, from the mid-1950s farmers began planting cash crops like tobacco and sugar cane more widely. Likewise, rice and wheat cultivation was introduced to Khet lands after the irrigation facility was established. Later, potato and spring paddy were also introduced. In fact, irrigation was the main reason for the onset of intensified agriculture in the watershed (Dahal et al., 2009). Although the introduction of the irrigation canals motivated farmers to adopt different crops, the system became inadequate as AI increased. Farmers in the area observed how an NGO called CEAPRED (the Center for Environmental and Agricultural Policy Research, Extension \& Development) implemented micro-irrigation schemes in nearby watersheds. Farmers in the Ansikhola watershed were then able to benefit from expanded and improved irrigation facilities with the assistance of the same project. This indicates that irrigation, as one of the four input priorities set by the government in the Agricultural Perspective Plan, is contributing to the adoption of crop intensification among farmers. Notably, the aim of increasing food production and raising farmers' economic conditions through AI can be enhanced by promoting irrigation schemes.

The provision of support services, such as credit, has been shown to increase the adoption of improved technologies (Paudel \& Thapa, 2004; Tiwari et al., 2008a). Farmers without cash and no access to credit find it very difficult to obtain and adopt new technologies (Teressa, 1997). The results of this study indicate that the variable 'access to credit' has a positive and significant influence on the likelihood of adoption of AI, which is consistent with reports from previous studies (Katungi et al., 2011; Hazarika \& Alwang, 2003). Our group 
discussions and direct observation revealed that some innovative farmers run local retail fertilizer shops. Such retail shops, and other intermediaries such as vegetable collectors, retailers, and commission agents provide fertilizer on credit, particularly during times when it is in short supply elsewhere, or as part of a deal that farmers sell their produce to them at a favorable rate. The vegetable producers' cooperative at Kuntabesi encourages farmers to cultivate vegetables and provides credit to its members, since few farmers in the study area are able to obtain credit from the Agricultural Development Bank. A similar community project, run by CEAPRED, trained farmers in aspects such as vegetable production, vegetable marketing, plant protection, nutrition management, cooperative management etc. During their initial project period, farmers are provided with free vegetable seeds, while in subsequent years, CEAPRED provides them with credit facilities in order to promote vegetable farming. Thus, farmers who have access to credit can minimize their financial constraints and buy agricultural inputs more readily. Katungi et al. (2011) showed that farmers with access to credit applied $52 \mathrm{~kg} / \mathrm{ha}$ more fertilizer than those who did not. In Malawi, the national fertilizer policy led to a substantial increase in fertilizer application, which in turn has led to a rapid increase in food production (Dorward \& Chirwa, 2011). This evidence implies that agricultural policy should target the provision of credit facilities in order to encourage the adoption of AI.

There are mixed findings in the literature on the influence of landholding size on households' decisions whether or not to adopt new technologies (Kassie et al., 2009; Waithaka et al. 2007; Coady, 1995). However, this study found that landholding has a positive and significant relationship with the adoption of AI in two different ways. Firstly, the size of the landholding directly influences the amount of cash income that farmers are able to accrue by cultivating commercial vegetables. Secondly, farmers with larger landholding size can more easily bear risks such as crop failure, and can better afford expenditure on farm machinery, by virtue of their higher income. The result is consistent with findings from Nepal \& Thapa (2009). Modern farm machinery contributes to utilizing lands more efficiently. We conclude that farmers who have relatively large landholdings will be more willing to adopt AI.

The results of the binary logistic regression model show that the distance of the homestead from the chemical fertilizer store has a significant negative influence on the adoption of AI. Farm houses located further away from the market are expected to face greater difficulties in obtaining timely access to the supply of agro-inputs. The finding is consistent with other study (Adesina, 1996). These days the majority of the farmers buy fertilizers from local retail fertilizer stores and cooperatives (Fig 3a), and some farmers even run local retail fertilizer stores at Kuntabesi, which is the nearest local market. Otherwise farmers would have to buy chemical fertilizers from the nearest towns, Banepa and Nala, which are approximately $13 \mathrm{~km}$ from the study area (Fig $3 \mathrm{~b}$ ). Due to the bulky nature of farmyard manure and the high transportation costs for its use in distant lands, farmers are more likely to use such manure in nearby homestead lands (Nkamleu \&Adesina, 2000). For Khet lands that are far from the farm houses, nutrient input is supplied mostly through the application of chemical fertilizer. The proximity of the chemical fertilizer store thus enhances the availability of chemical fertilizer, leading to greater adoption of crop intensification.

\subsection{Factors influencing the extent of AI}

Fourteen independent variables were included in the stepwise linear regression model and were significantly correlated with the extent of AI. Both R and R squared values increased with the addition of independent variables and significantly explain the model (Table 4). The final model with three independent variables, namely total amount of fertilizer used by farmers, net income from cereals and vegetables, and distance to the chemical fertilizer, store explains $78 \%$ of the variation in the extent of the area under crop intensification. The total amount of fertilizer used by farmers has the highest explanatory power (nearly $97 \%$ ) for the variation in the extent of AI (Table 4).

The area under AI varied from one household to another. The three factors, namely: amount of chemical fertilizers, net income from cultivating vegetables and cereals, and distance to chemical fertilizer store, significantly explained the variation in the extent of AI in the study area (Table 5). Of the three significant factors, the amount of fertilizer applied appears to be the most influential, with a unit increment leading to an increase in the extent of area under AI by about 0.87 units. The net income from cereals and vegetables is the second most important variable, with a unit increment leading to an increase in the extent of area under AI by about 0.13 units.

Many studies in the literature reveal that the application of chemical fertilizers led to diminishing productivity and soil fertility, resulting in low crop production in the long term (Bajracharya, 2002; Karki 2006). However, in this study area there is an increasing tendency to apply chemical fertilizer to cash crops like potato, bitter gourd, tomato, etc. Farmers accrue cash income by selling vegetables due to the high market value of these crops. Thus, the increasing application of fertilizers measured in $\mathrm{kg}$ per ha and the net income accrued from selling cereals and vegetables due to the high market value of these crops, imply tendencies towards increasing the area under the three cropping system. 
The results of this study reveal that a unit increase in the distance to the chemical fertilizer store has a negative change by about 0.1 units in the area under the three cropping system, suggesting that farmers do not practice intensive agriculture when chemical fertilizers have to be bought from distant fertilizer stores. This is a sensible correlation, which was expected. About three decades ago, farmers had to buy chemical fertilizers from the town market which is more than $13 \mathrm{~km}$ away from the study area, and thus intensive agriculture was not evident at that time. As retail fertilizer stores became available locally, for example at Kuntabesi in the vicinity of the watershed, the tendency towards intensive farming has increased, suggesting an increase in the area under the three cropping system. This implies that farmers who can afford greater amounts of fertilizers due to shorter distance to the chemical fertilizer store have adopted larger areas under crop intensification. Thus in order to encourage farmers to increase areas under intensification, there should be an improvement in the timely supply of fertilizers in the local retail shops. Efforts should also be made to provide information on appropriate amount of chemical fertilizers to be used for the crops by improving agricultural extension services.

\section{Conclusion and policy implications}

This study analyzed various factors influencing farmers' decisions about the adoption of intensive agricultural methods. The findings show that irrigation facilities, yield, access to credit, size of landholding, and distance to the chemical fertilizer store play influential roles in the adoption of AI. These findings reinforce the diffusion of innovations model (Rogers, 1995) in the sense that intensive agriculture is a gradual process and is influenced by several socio-economic and institutional factors. The Agricultural Perspective Plan (APP) of Nepal (APP, 1995) prioritized irrigation, fertilizer use, technology, and infrastructure in order to increase production through yield-increasing technological changes, more intensive use of land, and switching to high-value crops. This study shows that the amount of fertilizer application, income from vegetables and cereals, and distance from the chemical fertilizer store explain the variation in the area under AI in the Ansikhola watershed in the central mid-hills of Nepal. Thus the availability of resources, the institutions through which resources are accessed, and the policy context all influence the path of AI.

As can be seen from several studies, there seems to be a difference in the relative importance of factors determining land users' farming decisions. The relative significance of influencing factors may also vary for farmers under varying socio-economic and agro-ecological conditions. The results of this study have significant policy implications for sustainable agricultural intensification in the study area and in other mid-hill watersheds under similar bio-physical and agro-ecological conditions. The focus of the Agricultural Perspective Plan of Nepal on capital-led paths of intensification, and the emergence of recent market opportunities have increased the application of chemical fertilizers more than any other interventions. The majority of farmers in the area are inclined towards a disproportionate use of nitrogenous fertilizers like urea, rather than $\mathrm{N}, \mathrm{P}$ and $\mathrm{K}$ fertilizers, mainly due to the low price of urea and ignorance about the balanced use of fertilizers. Many farmers showed a concern about the lack of soil nutrients, which may imply that the extension services have weakened and extension agents lack the incentive to provide proper guidance to farmers. Thus, sustainable agricultural intensification can be achieved by improving extension programs (inputs, new technology), credit provision, infrastructural services and the promotion of irrigation facilities.

\section{Acknowledgements}

Financial support for this research as part of the project 'Education Research and Training for Sustainable Management of Natural Resources in Himalayan Watersheds', IOF/UMB project (PRO 2007/10109), was provided by the Norwegian Council for Higher Education's Program for Development Research and Education (NUFU).

\section{References}

Adesina, A. A. (1996). Factors Affecting the Adoption of Fertilizers by Rice Farmers in Cote d'Ivoire. Nutrient Cycling in Agroecosystems. 46, 29-39. doi: 10.1007/BF00210222, http://dx.doi.org/10.1007/BF00210222

APP (1995). Agricultural Perspective Plan (Final Report). National Planning Commission. Agricultural Projects Service Centre. Kathmandu, Nepal.

Bajracharya, R. M. (2002). Fertility and productivity parameters for soil from five mid-hill districts of central Nepal. In: Procs. Int'l. Seminar on Mountains, Royal Nepal Academy of Science and Technology, Kathmandu, Nepal.

Bajracharya, R. M., \& Sherchan, D. P. (2009). Fertility status and dynamics of soils in the Nepal Himalaya: A review and analysis. In: Lucero, D.P. \& Boggs, J.E. Soil Fertility. New York: Nova Science Publishers, Inc.

Boserup, E. (1965). The conditions of agricultural growth: The economics of agrarian change under population pressure. London: Earthscan Publications Ltd.

Brown, S., \& Shrestha, B. (2000). Market-Driven Land-Use Dynamics in the Middle Mountains of Nepal, Journal of Environmental Management. 59, 217-225. doi: 10.1006/jema.2000.0355, http://dx.doi.org/10.1006/jema.2000.0355 
Carswell, G. (2000). Agricultural intensification in Ethiopia and Mali. IDS Report 48. Brighton, UK: Institute of Development Studies.

CBS (2002). Statistical pocket book of Nepal 2002, Central Bureau of Statistics, Kathmandu.

CBS (2003) Statistical Yearbook Nepal 2003, Kathmandu: Central Bureau of Statistics.

Chapagain, P. S. (2006). Involution or Evolution? Conceptualizing the Changes in Farming System of Eastern Nepal. The Himalayan Review. 37, 1-17.

Christaller, W. (1933). Die zentralen Orte in Suddeutschland. Jena: Gustav Fischer. Translated in part, by Charlisle W. Baskin, as Central Places in Southern Germany. Prentice Hall, 1966.

Coady, D. (1995). An empirical Analysis of Fertilizer Use in Pakistan. Economica. 62 (246), 213-234.

Dahal, B. M., Sitaula, B. K., Sharma, S., \& Bajracharya, R. (2007). Effects of Agricultural Intensification on the Quality of Rivers in Rural Watersheds of Nepal. Journal of Food, Agriculture \& Environment. 5 (1), 341-347.

Dahal, B. M., Nyborg, I., Sitaula, B. K., \& Bajracharya, R. (2009). Agricultural Intensification: Food Insecurity to Income Security in a Mid-Hill Watershed of Nepal. International Journal of Agricultural Sustainability. 7 (4), 249-260. doi: 10.3763/ijas.2009.0436, http://dx.doi.org/10.3763/ijas.2009.0436

Douglass, M. (1998). A Regional Network Strategy for Reciprocal Rural-Urban Linkages: an agenda for policy research with refrence to Indonesia. Third World Planning Review. 20 (1), 1-34.

Dorward, A., \& Chirwa, E. (2011). The Malawi Agricultural Input Subsidy Programme: 2005-06 to 2008-09. International Journal of Agricultural Sustainability. 9 (1), 232-247. doi: 10.3763/ijas.2010.0567, http://dx.doi.org/10.3763/ijas.2010.0567

DFID (2002). Better livelihoods for poor people: The role of agriculture. UK: Department for International Development.

Ellis, F. (1989). Peasant Economics. (2 ${ }^{\text {nd }}$ ed.) (Chapter 5). Cambridge: Cambridge University Press,

Fafchamps, M., \& Shilpi, F. (2003). The Spatial Division of Labor in Nepal. The Journal of Development Studies. 39, 23-66. doi: 10.1080/00220380312331293577, http://dx.doi.org/10.1080/00220380312331293577

Hazarika, H., \& Alwang, J. (2003). Access to Credit, Plot Size and Cost Inefficiency Among Smallholder Tobacco Cultivators in Malawi. Agricultural Economics. 29 (1), 99-109. doi: 10.1111/j.1574-0862.2003.tb00150.x, http://dx.doi.org/10.1111/j.1574-0862.2003.tb00150.x

Johnson, E. A. J. (1970). The organization of space in developing countries. Harvard University Press.

Karki, K. B. (2006). Impact of cropping intensification on nutritional balance in Nepalese soils, In: Procs. Int'l. Seminar on Environment and Social Impacts of Agricultural Intensification in Himalayan Watersheds. Kathmandu Nepal.

Katungi, E., Horna, D., Gebeyehu, S., \& Sperling, L. (2011). Market Access, Intensification and Productivity of Common Bean in Ethopia: A microeconomic analysis. African Journal of Agricultural Research. 6 (2), 476-487.

Kassie, M., Zikhali, P., Manjur, K., \& Edwards, S. (2009). Adoption of Sustainable Agriculture Practices: Evidence from a Semi-Arid Region of Ethiopia. Natural Resources Forum. 33, 189-198. doi: 10.1111/j.1477-8947.2009.01224.x, http://dx.doi.org/10.1111/j.1477-8947.2009.01224.x

Knowler, D., \& Bradshaw, B. (2007). Farmer's Adoption of Conservation Agriculture: A Reviw and Synthesis of Recent Research. Food Policy. 32, 25-48. doi: 10.1016/j.foodpol.2006.01.003, http://dx.doi.org/10.1016/j.foodpol.2006.01.003

Lapar, M. L. A., \& Ehui, S. K. (2004). Factors Affecting Adoption of Dual-Purpose Forage in the Philippine uplands. Agriculture Systems. 81, 95-114. doi: 10.1016/j.agsy.2003.09.003, http://dx.doi.org/10.1016/j.agsy.2003.09.003

Lele, U., \& Stone, S. W. (1989). Population pressure, the environment and agricultural intensification in Sub-Saharan Africa; variations on the Boserup Hypothesis. Managing Agricultural Development in Africa (MADIA) Study. Washington: World Bank.

Long, S. T., \& Freese, J. (2006). Regression model for categorical dependent variables using stata. Texas: A Stata Press Publication, College Station.

Nepal, R., \& Thapa, G. B. (2009). Determinants of Agricultural Commercialization and Mechanization in the Hinterland of a City in Nepal. Applied Geography. 29, 377-389. doi: 10.1016/j.apgeog.2008.12.002, http://dx.doi.org/10.1016/j.apgeog.2008.12.002

Nkamleu, G. B., \& Adesina, A. A. (2000). Determinants of Chemical Input use in Peri-Urban Lowland Systems: Bivariate Probit Analysis in Cameroon. Agricultural Systems. 63, 111-121. doi: 10.1016/S0308-521X(99)00074-8, http://dx.doi.org/10.1016/S0308-521X(99)00074-8

Panth, M., \& Gautam, J. (1987). Mountain farming systems in Nepal. New Delhi: Oxford. 
Paudel, G. S., \& Thapa, G. B. (2004). Impact of Social, Institutional and Ecological Factors on Land Management Practices in Mountain Watersheds of Nepal. Applied Geography. 24, 35-55. doi: 10.1016/j.apgeog.2003.08.011, http://dx.doi.org/10.1016/j.apgeog.2003.08.011

Pingali. P., Bigot, Y., \& Binswanger, H. (1987). Agricultural mechanization and the evolution of farming system in Sub-Saharan Africa. Baltimore: Johns Hopkins University Press.

Pingali, P. L., \& Rosegrant, M. W. (1995). Agricultural Commercialization and Diversification: Processes and Policies. Food Policy. 20, 171-185. doi:10.1016/0306-9192(95)00012-4, http://dx.doi.org/10.1016/j.apgeog.2003.08.011

Rogers, E. M. (1995). Diffusion of innovations (4th ed.). USA. New York: The Free University Press.

Schreier, H., Shah, P. B., Lavkulich, L., \& Brown, S. (1994). Maintaining Soil Fertility Under Increasing Land Use Pressure in the Middle Mountains of Nepal. Soil Use Manage. 10, 137-142. doi: 10.1111/j.1475-2743.1994.tb00474.x, http://dx.doi.org/10.1016/j.apgeog.2003.08.011

Schultz, T. W. (1964). Transforming traditional agriculture. New Haven, CT: Yale University Press.

Sharma, J. R. (2008). Practices of Male Labour Migration from the Hills of Nepal to India. In Development Discourses: Which Pathology? Gender Technology and Development. 12 (3), 303-323.

Teressa, A. (1997). Factors Influencing Adoption And Intensity of Use of Fertilizer. The Case of Lume District, Central Ethiopia. Quarterly Journal of International Agriculture. 36, 173-187.

Thapa, G. B., \& Niroula, G. S. (2008). Alternative Options of Land Consolidation in the Mountains of Nepal: An Analysis Based on Stakeholders' Opinions. Land Use Policy. 25, 338-350. doi: 10.1016/j. landusepol.2007.09.002, http://dx.doi.org/10.1016/j. landusepol.2007.09.002

Thapa, G. B., \& Rattanasuteerakul, K. (2010). Adoption and Extent of Organic Vegetable Farming in Mahasarakham province, Thailand. Applied Geography, xxx. 1-9. doi: 10.1016/j.apgeog.2010.04.004, http://dx.doi.org/10.1016/j.apgeog.2010.04.004

Tiwari, K. R., Sitaula, B. K., Nyborg, I. L. P., \& Paudel, G. S. (2008a). Determinants of Farmers’ Adoption of Improved Soil Conservation Technology in a Middle Mountain Watershed of Central Nepal. Environmental Management. 42, 210-222. doi: 10.1007/s00267-008-9137-z, http://dx.doi.org/10.1007/s00267-008-9137-z

Tiwari, K. R., Nyborg, I. L. P., Sitaula, B. K., \& Paudel, G. S. (2008b). Analysis of the Sustainability of Upland Farming Systems in the Middle Mountains Region of Nepal. International Journal of Agricultural Sustainability. 6 (4), 289-306. doi: doi:10.3763/ijas.2008.0390, http://dx.doi.org/10.3763/ijas.2008.0390

Westarp, S. V., Schreier, H., Brown, S., \& Shah, P. B. (2004). Agricultural Intensification and the Impacts on Soil Fertility in the Middle Mountains of Nepal. Canadian Journal of Soil Science. 84 (3), 323-332.

Waithaka, M. M., Thornton, P. K., Shepherd, K. D., \& Ndiwa, N. N. (2007). Factors Affecting the Use of Fertilizers and Manure by Smallholders: the Case of Vihiga, Western Kenya. Nutr Cycl Agroecosyst. 78, 211-224. doi: 10.1007/s10705-006-9087-x, http://dx.doi.org/ 10.1007/s10705-006-9087-x.

Weitz, R., David, P., \& Levia, A. (1976). New settlements and employment. Rehovet: Settlement Study Center. Xuefeng, H., Huhua, C., \& Fengmin, L. (2008). Factors Influencing the Adoption of Pasture Crop Rotation in the Semiarid Area of China's Loess Plateau. Journal of Sustainable Agriculture. 32 (1), 161-180. doi: 10.1080/10440040802121551, http://dx.doi.org/ 10.1080/10440040802121551.

Table 1. Major cropping patterns in the Ansikhola watershed

\begin{tabular}{|l|l|l|}
\hline Cultivated land types & Cropping pattern (3 crops) & Cropping pattern (2 crops) \\
\hline Galkhet & Rice-potato-rice & Rice-rice \\
\cline { 2 - 2 } & Rice-potato-maize/ Rice-maize-rice & Rice-maize \\
\hline \multirow{2}{*}{ Tarkhet } & Rice-potato-maize & Rice-maize \\
\cline { 2 - 2 } & Rice-potato-vegetables & \\
\cline { 2 - 3 } & Rice-potato-tomato & Maize-potato \\
\hline Gharbari & Vegetable-maize-potato/ maize-mustard-potato & Maize-millet \\
\hline Pakhobari & Chilly-vegetable-potato & Maize-millet/Maize-wheat \\
\hline
\end{tabular}


Table 2. Description and summary statistics (mean and percentage) of the variables used in the binary logistic model $(n=310)$

\begin{tabular}{|c|c|c|c|c|}
\hline Variable & Description & Adopters & Non-adopters & Significance \\
\hline Adoption & Dependent variable: adoption of agricultural intensification & $n=195$ & $n=115$ & \\
\hline \multirow[t]{3}{*}{ Caste $^{\mathrm{a}}$} & Caste of the respondents (\%) & & & 0.35 \\
\hline & Brahmin/Chhetri (\%) & 60 & 40 & \\
\hline & Others $(\%)$ & 65 & 35 & \\
\hline \multirow[t]{3}{*}{ Gender $^{\mathrm{a}}$} & Sex of the respondent (\%) & & & 0.29 \\
\hline & Male (\%) & 61 & 39 & \\
\hline & Female (\%) & 65 & 35 & \\
\hline \multirow[t]{5}{*}{ Education $^{\mathrm{a}}$} & Education of the respondent (\%) & & & 0.19 \\
\hline & Illiterate (\%) & 66 & 34 & \\
\hline & Primary (\%) & 50 & 50 & \\
\hline & Secondary $(\%)$ & 59 & 41 & \\
\hline & Higher secondary and above (\%) & 70 & 30 & \\
\hline \multirow[t]{3}{*}{ Occupation $^{\mathrm{a}}$} & Occupation of the respondent (\%) & & & 0.58 \\
\hline & Agriculture (\%) & 63 & 37 & \\
\hline & Others $(\%)$ & 62 & 38 & \\
\hline Distance $^{\mathrm{b}}$ & Distance to farm plots from farm house $(\mathrm{km})$ & 0.75 & 0.58 & 0.56 \\
\hline Yield $^{b}$ & $\begin{array}{l}\text { Crop yield (kg/hectare/year) (composite yield of maize and } \\
\text { rice) }\end{array}$ & 4101 & 3659 & $0.00^{\mathrm{c}}$ \\
\hline Labor input $^{\mathrm{b}}$ & Labor input (workdays/hectare/year) & 207 & 179 & $0.00^{\mathrm{c}}$ \\
\hline CF distance ${ }^{b}$ & Distance to chemical fertilizer store $(\mathrm{km})$ & 3.430 & 3.230 & 0.95 \\
\hline $\begin{array}{l}\text { Landholding } \\
\text { size }^{\mathrm{b}}\end{array}$ & Galkhet landholding size (hectare/hh) & 0.18 & 0.13 & $0.08^{\mathrm{e}}$ \\
\hline Income $^{b}$ & Net income from vegetables and cereals (NRs) & 13230 & 11814 & 0.54 \\
\hline Irrigation $^{\mathrm{b}}$ & Irrigation (frequency/year) & 8.860 & 2.750 & $0.04^{\mathrm{d}}$ \\
\hline $\mathrm{LSU}^{\mathrm{b}}$ & Cattle herd size (head/hh) & 1.062 & 1.096 & 0.50 \\
\hline Credit $^{\mathrm{a}}$ & Access to credit & 64 & 36 & $0.03^{\mathrm{d}}$ \\
\hline Help $^{\mathrm{a}}$ & Frequency of assistance received from extension workers & 63 & 37 & 0.24 \\
\hline
\end{tabular}


Table 3. Maximum likelihood estimates of the AI adoption model

\begin{tabular}{|l|l|l|l|l|}
\hline Variables & Coefficient & S.E. & Sig. & Odds ratio \\
\hline Caste & -0.073 & 0.353 & 0.836 & 0.930 \\
\hline Gender & 0.310 & 0.356 & 0.384 & 1.363 \\
\hline Education of the respondent & -0.224 & 0.240 & 0.351 & 0.799 \\
\hline Occupation & -0.124 & 0.824 & 0.880 & 0.884 \\
\hline Agricultural labor input (workdays ha-1 per year) & -0.004 & 0.004 & 0.294 & 0.996 \\
\hline Cattle herd size (LSU*) & 0.021 & 0.137 & 0.879 & 1.021 \\
\hline Landholding size (ha per household) & 3.649 & 1.772 & $0.039^{* *}$ & 38.438 \\
\hline Distance to farm plots from farmhouse (km) & 0.157 & 0.173 & 0.362 & 1.170 \\
\hline Crop yield (kg ha per year) & 0.002 & 0.001 & $0.020^{* *}$ & 1.002 \\
\hline Income (net income from cereals and vegetables in NRs) & 0.001 & 0.000 & 0.506 & 1.001 \\
\hline Irrigation (frequency per year) & 0.989 & 0.119 & $0.000^{*}$ & 2.689 \\
\hline Distance to chemical fertilizer store (km) & -0.233 & 0.115 & $0.042^{* *}$ & 0.792 \\
\hline Access to credit & 1.010 & 0.516 & $0.050^{* * *}$ & 2.746 \\
\hline Frequency of assistance received from extension workers & -0.195 & 0.392 & 0.620 & 0.823 \\
\hline Constant & -6.956 & 1.889 & 0.000 & 0.001 \\
\hline
\end{tabular}

Hosmer and Lemeshow Test: Chi-square $=5.144$, d.f. $=8$, Sig. $=0.742,-2$ Log likelihood $=221.889$, Cox \& Snell $\mathrm{r}^{2}=0.45$; Nagelkerke $\mathrm{r}^{2}=0.62$; overall percentage of right prediction $=86 \%$; sample size $=310$ households.

${ }^{*} \mathrm{p}<0.001,{ }^{* *} \mathrm{p}<0.05,{ }^{* * *} \mathrm{p}<0.1$

Table 4. Summary of the extent of the AI model

\begin{tabular}{|l|r|l|l|l|l|l|}
\hline Model & \multicolumn{1}{|l|}{$\mathrm{R}$} & \multicolumn{1}{|l|}{ R square } & \multicolumn{1}{|l|}{ Adjusted R square } & \multicolumn{2}{|l|}{ Standard error of the estimate } \\
\hline 1 & $0.871^{\mathrm{a}}$ & 0.758 & 0.757 & 0.076 & & \\
\hline 2 & & & & & & \\
\hline 3 & $0.881^{\mathrm{b}}$ & 0.776 & 0.774 & 0.073 & & \\
\hline
\end{tabular}

${ }^{\text {a }}$ Predictors: (Constant), Total amount of fertilizer used by farmers.

${ }^{\mathrm{b}}$ Predictors: (Constant), Total amount of fertilizer used by farmers and net income from cereals and vegetables.

${ }^{\mathrm{c}}$ Predictors: (Constant), Total amount of fertilizer used by farmers; net income from cereals and vegetables and distance to chemical fertilizer store.

Table 5. Coefficients of independent variables included in the extent of the AI model

\begin{tabular}{|c|c|c|c|c|}
\hline & $\begin{array}{l}\text { Unstandar } \\
\text { Coefficien }\end{array}$ & zed & $\begin{array}{l}\text { Standardized } \\
\text { Coefficients }\end{array}$ & t Significance \\
\hline & B & Std. Error & (Beta) & \\
\hline (Constant) & -0.040 & 0.014 & & -2.9300 .004 \\
\hline Total amount of fertilizer applied in Galkhet & 0.001 & 0.000 & 0.870 & $25.4430 .000^{*}$ \\
\hline $\begin{array}{l}\text { Net income from cereals and vegetables (in } \\
\text { NRs) }\end{array}$ & $1.083 \mathrm{E}-6$ & 0.000 & 0.130 & $3.8340 .000^{*}$ \\
\hline Distance to chemical fertilizer store $(\mathrm{km})$ & -0.008 & 0.003 & -0.089 & $-2.6240 .009^{* *}$ \\
\hline
\end{tabular}




\section{List of figures}

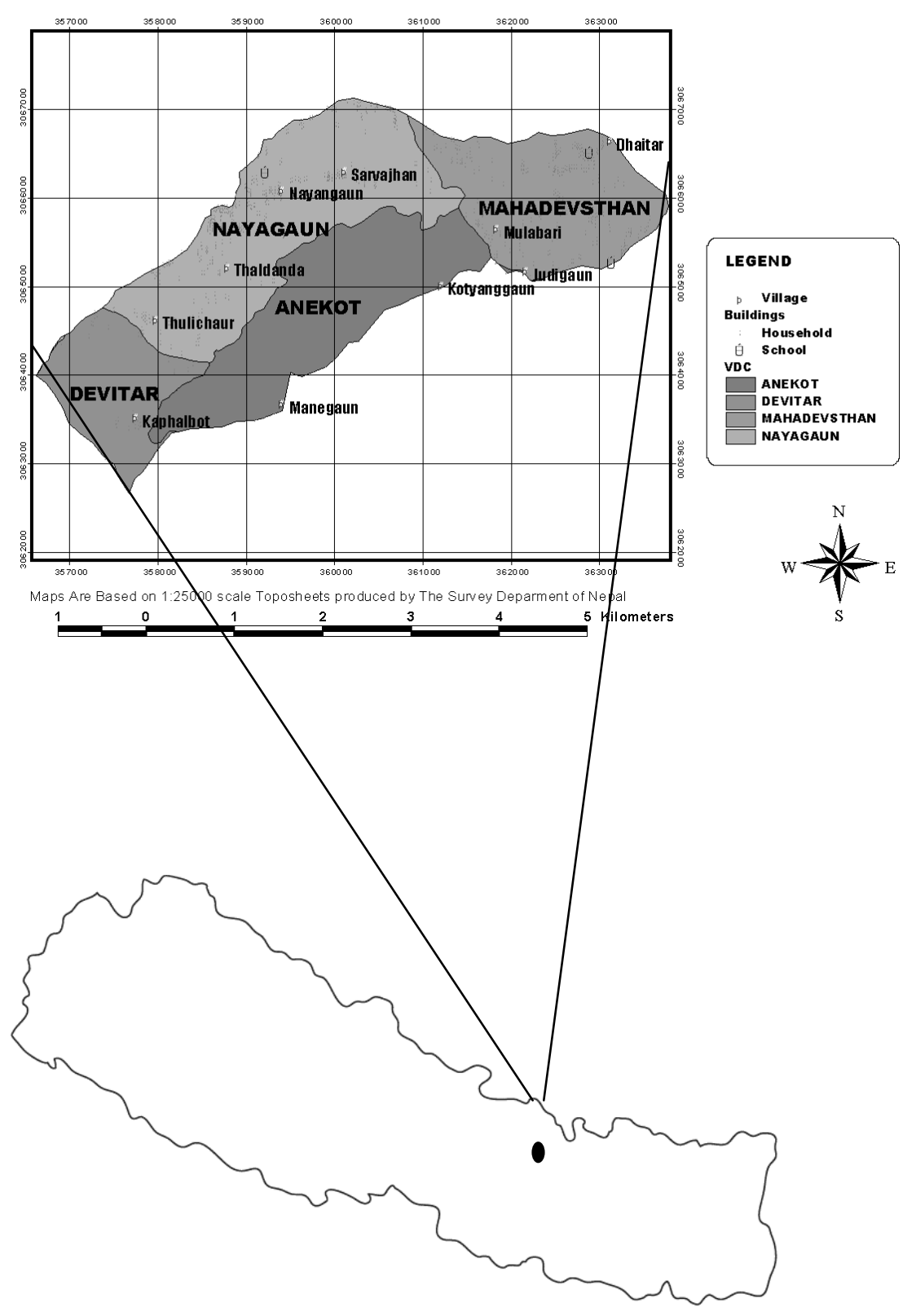

Figure 1. Location of the study area (Ansikhola watershed) 


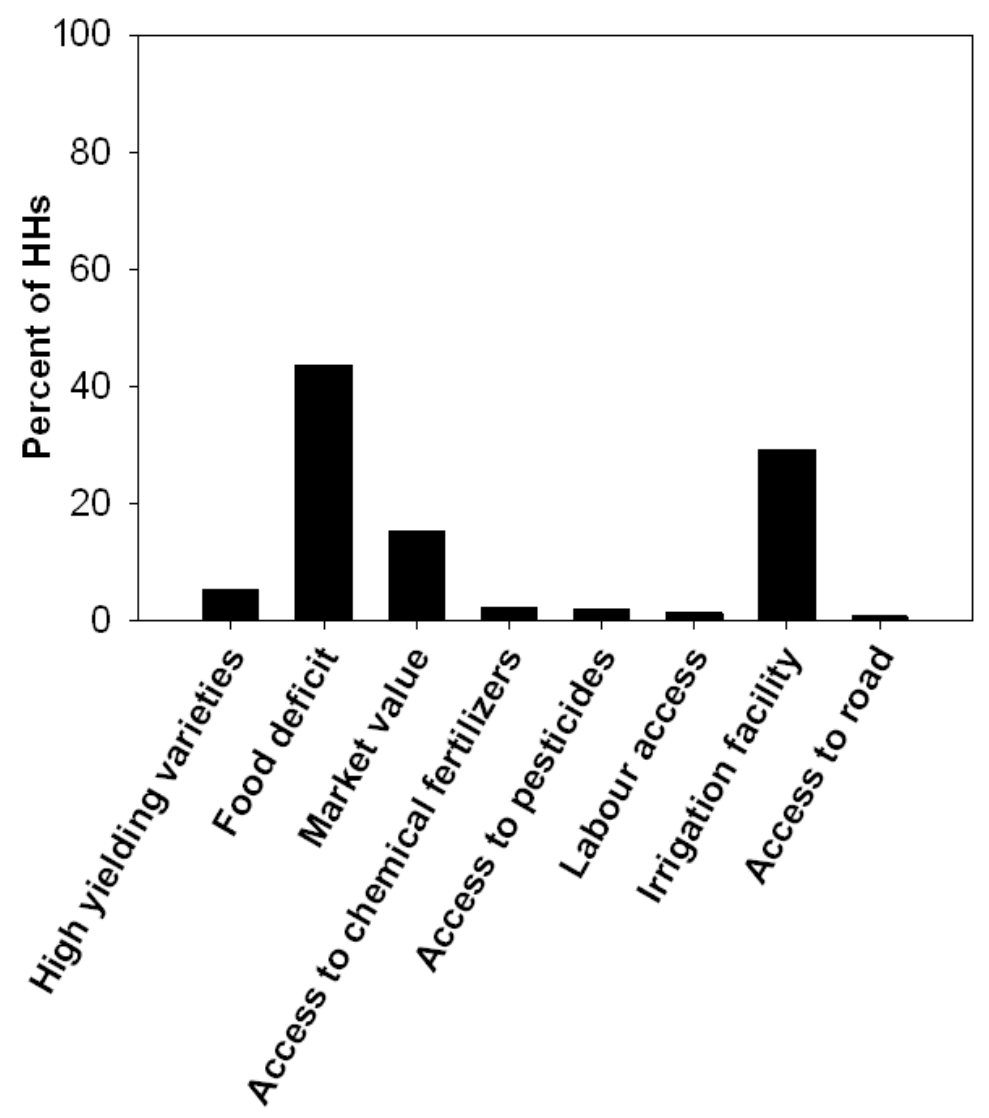

Figure 2. Motivating factors for adoption of the three cropping system

\section{Nearest chemical fertilizer stores}

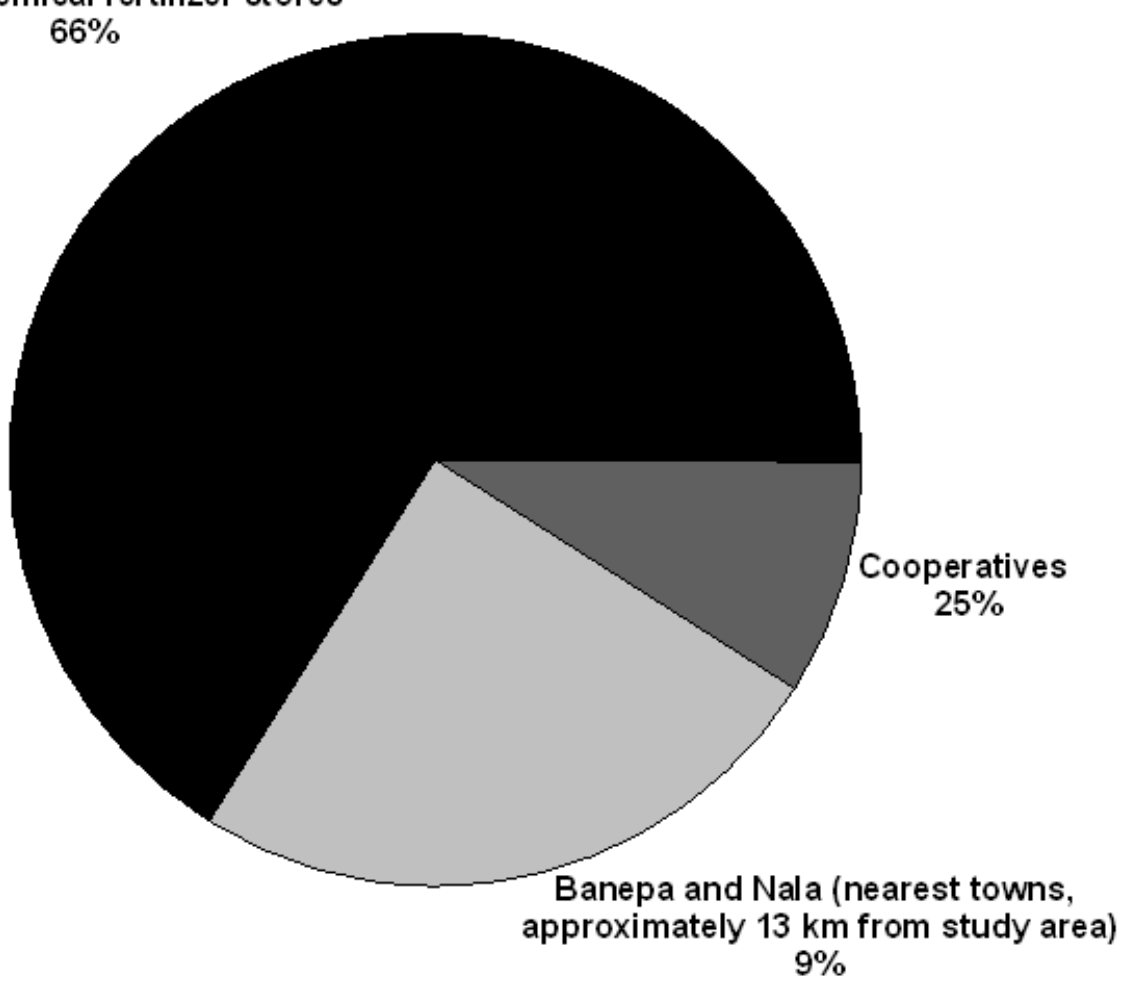

Figure 3a. Percentage of households buying chemical fertilizers from different sources in 2009 


\section{Banepa and Nala (nearest towns,} approximately $13 \mathrm{~km}$ from study area)

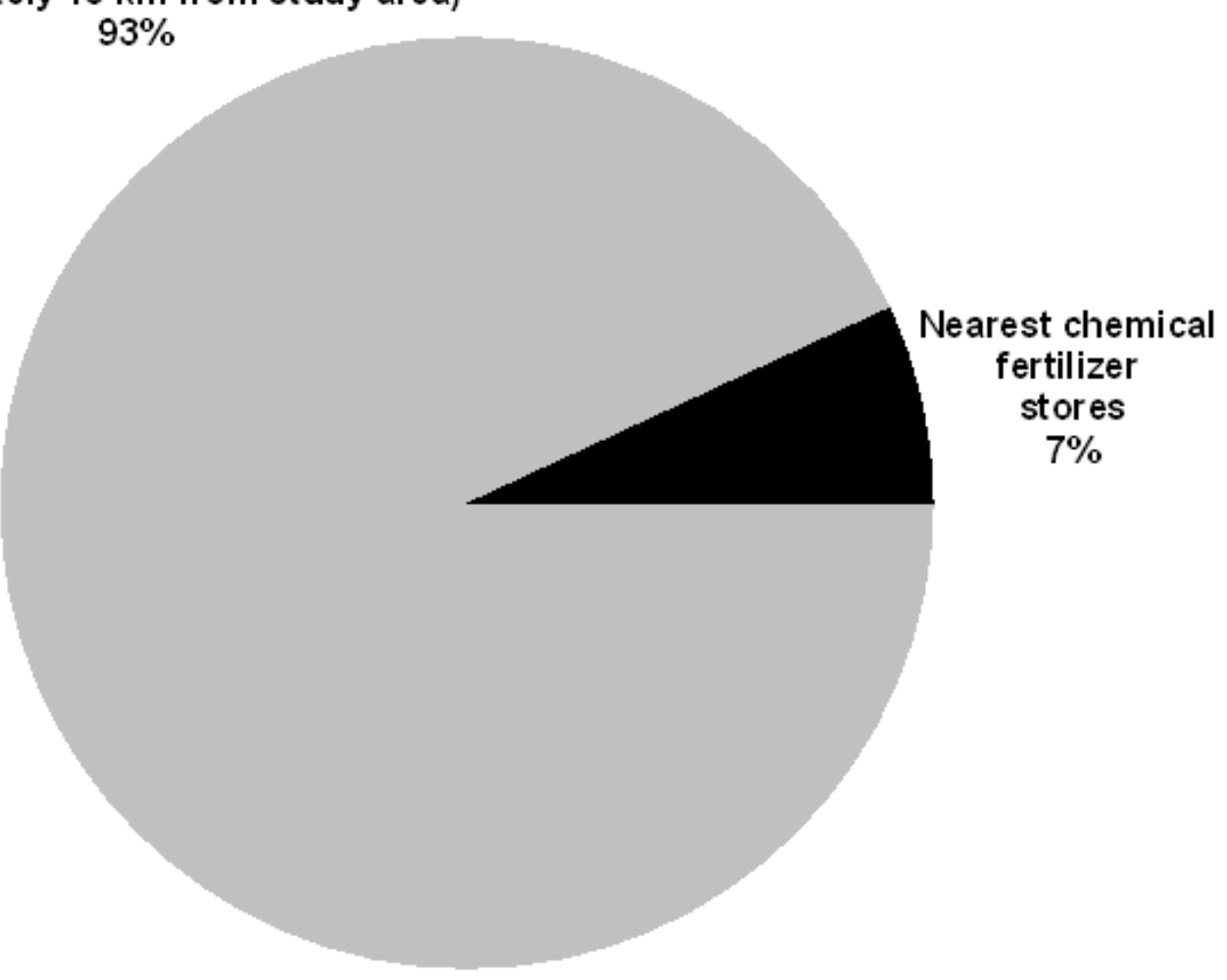

Figure 3b. Percentage of households buying chemical fertilizers from different sources in 1989 